\title{
52 - Osteopatia crânio-mandibular. Relato de caso
}

Gonçalves,S.'; Pinto, C.F.2; Oliveira ,S.M. ${ }^{3}$; Rocha, A.D. ${ }^{4}$
Cury,C.M.'; Jericó,M.M.²
1- Médica Veterinária do Setor de Clinica Médica do Hospital Veterinário da Universidade Santo Amaro e pós-graduanda do Setor de Cirurgia da Faculdade de Medicina Veterinária da Universidade de São Paulo, São Paulo-SP

2- Médica Veterinária Residente do Setor de Clínica Médica do Hospital Veterinário da Universidade Santo Amaro, São Paulo-SP

3- Professora Assistente da Disciplina de Diagnóstico por Imagem a Faculdade de Medicina Veterinária da Universidade de Santo Amaro, São Paulo-SP

4-Médica Veterinária Residente do Setor de Diagnóstico por Imagem do Hospital Veterinário da Universidade Santo Amaro, São Paulo-SP

A osteopatia crânio mandibular, também denominada osteopatia temporomandibular ou periostite mandibular, é um distúrbio não neoplásico caracterizado por proliferação óssea que afeta quase que, exclusivamente, os ossos do crânio e mandíbula, principalmente bulas timpânicas e ossos frontal, parietal e maxilar podendo ocasionar anquilose da articulaçào temporomandibular. As raças predispostas são West Highland White Terrier, Scottish e Cain Terrier com provável etiologia genética. Os principais sinais e sintomas clínicos são dificuldade de apreensão dos alimentos, edema mandibular, dor e febre demonstrados entre 3 e 8 meses de idade. Relata-se a ocorrência de 3 cães, 2 fêmeas e 1 macho, de uma mesma ninhada, 2 meses de idade, da raça Scottish Terrier, que apresentavam dor e dificuldade na apreensào de alimentos. Ao exame fisico, os càes demonstravam relutância à manipulação da mandỉbula e má oclusão dentária. O exame radiográfico revelou espessamento ósseo dos ramos mandibulares, ossos frontais, parietais, occipital e bulas timpânicas compativeis com osteopatia crânio mandibular. Convém referir a presença de um filhote macho saudável, pertencente à mesma ninhada, dentro dos padròes de normalidade clínica e radiográfica auxiliando na determinação do diagnóstico de forma comparativa. $\mathrm{O}$ tratamento preconizado em literatura é baseado na utilização de antiinflamatórios nào esteroidais, e em casos mais severos, corticóides para alivio dos sintomas. Enfatiza-se a importância da documentaçào deste caso por ser uma enfermidade de provável caráter genético em raças emergentes na clinica de pequenos animais.

\section{3 - Caracterização clínica dos cães diabéticos atendidos no Hovet Unisa}

1-Aluno de iniciação científica do Hospital Veterinário da Faculdade de Medicina Veterinária da Universidade de Santo Amaro, São Paulo-SP

2-Professor da Faculdade de Medicina Veterinária da Universidade de Santo Amaro, Universidade Bandeirantes e Anhembi-Morumbi, São Paulo-SP

A diabetes mellitus, doença endócrina freqüente na espécie canina, caracteriza-se pelo comprometimento da funçào das células b das illhotas de Langerhans do pâncreas, levando a uma perda progressiva e, eventualmente, completa da secreção de insulina. Objetivou-se a avaliaçào dos aspectos clínicos de càes diabéticos, ainda não submetidos à insulinoterapia, identificados à partir de valores de glicemia $(>180 \mathrm{mg} / \mathrm{dl})$ e da presença de glicosúria . No período de janeiro de 2002 a abril de 2003, foram atendidos no Hovet-Unisa 22 cães, sendo 18 fêmeas $(81.8 \%$ ) e quatro machos $(18.2 \%)$, dentre eles, nove cães sem raça definida $(40.9 \%)$, sete poodles $(31.8 \%)$, um pinscher $(4.54 \%)$, um pastor alemão $(4.54 \%)$, um rottweiller (4.54\%), um fila brasileiro (4.54\%), um coker spaniel ( $4.54 \%$ ) e um fox paulistinha $(4.54 \%)$. A variação de idade foi de 6 a 13 anos. Esses animais foram avaliados no que tange às alteraçōes de anamnese, exame fisico, hemograma, urinálise (realizada por cistocentese em 18 dos cães selecionados) e painel bioquímico. $\mathrm{Na}$ anamnese dos 22 cães atendidos, 21 apresentaram emagrecimento $(95.4 \%), 20$ cães demonstraram polidipsia e poliúria $(90.9 \%)$, onze tinham polifagia $(50 \%)$, três càes exibiram hiporexia e emese $(13.6 \%)$, dois tinham 
anorexia $(9 \%)$ e dois animais eram gonadectomizados $(9 \%)$. No exame fisico, onze cães exibiram catarata $(50 \%)$, onze apresentaram nódulos ou tumores mamários $(50 \%)$, dez animais estavam desidratados $(45.4 \%)$ e seis cães apresentaram disqueratoses $(27.2 \%)$. Em relação a urinálise, foi constatado que 18 cães tinham bacteriúria $(100 \%)$, onze exibiram cetonúria $(61.1 \%)$, dez demonstraram cristalúria $(55.5 \%)$ e oito cães tinham proteinúria $(44.4 \%)$. Na mensuração da bioquímica sérica, onze cães apresentaram hipercolesterolemia $(57.8 \%)$, oito animais demostraram aumento dos níveis séricos de transaminase pirúvica (ALT) e triglicerides $(42.1 \%)$ e dois cães tinham valores elevados de fosfatase alcalina $(10.25 \%)$. Através dos dados obtidos na população de animais estudada, foi possível concluir que a maioria dos cães diabéticos (mais de $50 \%$ deles), atendidos no Hovet-Unisa, era constituída por fêmeas, nào gonadectomizadas, com alterações clínicas representadas por emagrecimento, polidipsia, poliúria, polifagia, nódulos ou tumores mamários, e resultados de exames complementares caracterizados por hipercolesterolemia, bacteriúria cetonúria, e cristalúria. Estas observações visam auxiliar a conduta clínica quando do primeiro atendimento do cão diabético.

\section{4 - Estudo da longevidade de diferentes raças de cães na cidade de São Paulo}

Bentubo, H'; Cardoso, T.G.'; Rocha, L.F.'; Bondan, E.F.'; Lallo, M.A. ${ }^{1}$

\section{1- Universidade Paulista (UNIP), São Paulo-SP}

A idade é definida como um processo biológico complexo caracterizado pela redução da capacidade do indivíduo em manter a homeostasia, o que diminui sua viabilidade e aumenta a vulnerabilidade às doenças. Estudos revelam diferenças significantes na longevidade de cães de acordo com a raça, sendo que animais gigantes notadamente sobrevivem menos tempo que animais de raças pequenas. Outros fatores, tais como, genéticos, ambientais e nutricionais também se relacionam com o processo de envelhecimento. Faltam, no entanto, tais dados em relação à população canina no Brasil. O presente trabalho teve por objetivo avaliar a longevidade de cães de diversas raças na cidade de São Paulo, a fim de compreender suas relaçōes com alguns dos prováveis fatores de risco. Proprietários de cães já falecidos foram submetidos a um questionário com perguntas objetivas sobre idade de óbito dos animais, causa da morte, o sexo, a raça e a presença de outros fatores relacionados à sobrevida. Ao final da pesquisa, foram utilizadas as informações obtidas de 550 questionários, os quais foram compilados e analisados estatisticamente. A idade média geral de sobrevivência de todos os animais incluidos na pesquisa foi de 6 anos, tendo o animal mais velho morrido aos 22 anos. Animais sem raça definida apresentaram sobrevida média de 6 anos e 4 meses, enquanto que animais de raça definida viveram, em média, 5 anos e 8 meses. Em ordem decrescente de longevidade, as 10 raças mais prevalentes foram - Pequinês (11 anos, $\mathrm{n}=$ 13), Poodle ( 9 anos e 4 meses, $n=56$ ), Fox Paulistinha ( 9 anos e 2 meses, $n=19$ ), Dachshund ( 8 anos e 5 meses, $n=23$ ), Pastor Alemão ( 7 anos e 10 meses, $n=67$ ), Husky Siberiano ( 7 anos e 7 meses, $\mathrm{n}=11)$, Boxer ( 7 anos, $\mathrm{n}=11)$, Lhasa Apso ( 6 anos e 10 meses, $\mathrm{n}=23)$, Doberman ( 6 anos e 7 meses, $\mathrm{n}=11$ ) e Dog Alemão $(5$ anos e 7 meses, $\mathrm{n}$ =13). Com relação ao sexo, observou-se que as fêmeas viveram mais (média de 6 anos e 5 meses) que os machos (média de 5 anos e 5 meses). Animais castrados viveram em média mais tempo que os não castrados, sendo a sobrevida das fêmeas e machos castrados de, respectivamente, 11 anos e 5 meses e 8 anos e 9 meses. Os animais foram agrupados em 4

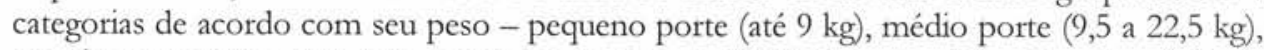
grande porte (23 a 40,5 kg) e gigantes (acima de 40,5 kg) e as médias de sobrevivência encontradas para cada classe foram, respectivamente, de 5 anos; 7 anos e 3 meses; 7 anos e 3 meses e 4 anos e 7 meses. De todos os animais investigados $10,72 \%$ morreram por causas naturais e $12,36 \%$ foram submetidos à eutanásia. Diferentes estados patológicos foram atribuídos à morte dos animais, sendo que as causas mais comumente observadas foram doenças infecciosas $(23,1 \%)$, traumas $(16,18 \%)$, neoplasias $(11,45 \%)$, intoxicações 